\title{
RESISTOGRAM TYPING-A NEW EPIDEMIOLOGICAL TOOL: APPLICATION TO ESCHERICHIA COLI
}

\author{
S. D. EleK AND LeONIE Higney \\ St George's Hospital Medical School, London
}

A T present typing within a bacterial species is restricted essentially to the use of serology, or of phage or colicine susceptibility. A hitherto unexplored approach is the differential effect exerted by some antibacterial compounds upon strains of a bacterial species. Many antibacterial substances when tested in critical concentrations and in very fine steps are capable of distinguishing between strains of a species. This has been overlooked in the past because antiseptics are commonly tested only in crude steps, and often against a single arbitrarily chosen "standard" organism of the species. In fact both phage and colicine typing are sophisticated forms of selective toxicity. The more immediate method of employing the selective toxicity of chemical substances has so far not been explored.

The approach--referred to here as " resistogram typing "-makes use of this observation. The principle is of general validity and can probably be extended to any commonly occurring microbe that has to be traced in the environment for epidemiological purposes. The method is very simple to carry out and may yield a useful system for typing bacteria for which so far no satisfactory method of typing exists. For other species it may form an adjunct extending the discrimination of existing forms of typing.

The present work is an illustration of the application of the principle to Escherichia coli in urinary infections. In this species serotyping is available, but phage and colicine typing have not proved of practical value. The purpose of the example is to show that the new method is capable of giving information of similar nature and value to that given by serotyping in this species.

\section{MATERIALS AND METHODS}

Strains. Sixteen randomly chosen strains of $E$. coli obtained from cases of urinary infection were used in establishing the resistogram system for this species.

Culture media. Difco Nutrient Broth was used throughout. The solid medium employed

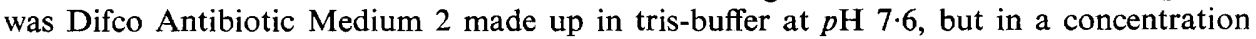
10 per cent. higher than that stated by the manufacturers to allow for the dilution caused by the addition of the antibacterial agent. All the plates used in the typing were poured with $30 \mathrm{ml}$ total volume of the agar medium to minimise concentration shifts due to drying.

\section{Antibacterial compounds and their screening}

A wide variety of both inorganic and organic compounds as well as dyes were tested. Antibiotics, whether in use for treatment or only as experimental compounds, were excluded.

Received 4 June 1969; accepted 14 July 1969.

J. MED. MICROBIOL.-VOL. 3 (1970) 
For the resistogram system here described, based on 8 substances, a total of 180 compounds had to be tested.

For the initial screening of the compounds the gradient plate method of Szybalski and Bryson (1952) was used. This gives an even fall of concentration of the compounds tested and provides a quick visual assessment of the extent of growth, and therefore of the discrimination between strains inoculated in parallel streaks. Varying concentrations of the compounds to be tested were incorporated in the agar medium and a wedge was poured and allowed to solidify in the tilted position. The plate was placed horizontally and an equal amount of the agar medium, without the compound, was poured over it. Two plates were used and 8 strains per plate were streaked across parallel to each other with a standard loopful of a 1 in 10 dilution of an overnight broth culture. In this way 34 compounds were chosen which showed considerable differences in their inhibitory action on the 16 test strains.

The wedge plate gave an approximate indication of the concentration around which the final titrations had to be done. Each of the 34 compounds was titrated by incorporating

TABLE I

Stock solutions for resistogram typing

\begin{tabular}{|c|c|c|}
\hline Reference letter & Substance & Concentration per cent. $(w / v)$ \\
\hline A & Sodium arsenate & 0.75 \\
\hline B & Phenylmercuric nitrate & 0.0006 \\
\hline $\mathrm{C}$ & $\begin{array}{l}4: 4^{\prime} \text {-Diamidinodiphenylamine } \\
\text { dihydrochloride }\end{array}$ & 0.005 \\
\hline $\mathrm{D}$ & Boric acid & $3 \cdot 0$ \\
\hline $\mathrm{E}$ & Acriflavine & 0.09 \\
\hline$\vec{F}$ & 4-Chloresorcinol & 0.7 \\
\hline $\mathrm{G}$ & Copper sulphate & 0.7 \\
\hline $\mathbf{H}$ & Malachite green & $0 \cdot 003$ \\
\hline
\end{tabular}

the substance in a range of small steps in agar, around the concentration indicated by the wedge plate. The test organisms were spot-inoculated, with an inoculum size of about 1000 organisms. In this way the concentration of the compound could be ascertained that when added in 3-ml amount to $27 \mathrm{ml}$ of agar gave good discrimination. When so tested, 26 of the compounds gave insufficient or unsatisfactory discrimination and were discarded. The remaining 8 were chosen as a basis for the resistogram system. Table I lists these substances and the working stock solutions. In practice it is not possible to obtain the exact concentration required without further biological titration against known sensitive and resistant strains. A correction factor is needed which must be used for each solution.

\section{Biological titration}

The 8 solutions given in table $\mathrm{I}$ are first prepared. To $27 \mathrm{ml}$ of the nutrient agar base $2 \cdot 6,2 \cdot 8,3 \cdot 0,3 \cdot 2$ and $3.4 \mathrm{ml}$ of each solution is added and, after mixing, plates are poured. The 16 test organisms are inoculated on to each plate, either with a loop or with the inoculating machine, with about 1000 organisms per inoculum. The standard pattern that should be obtained for the 16 organisms is shown in table II. The volume that yields this result with the standard strains is the correction figure, e.g., $2 \cdot 8 \mathrm{ml}$. This volume is then added to $27 \mathrm{ml}$ of the buffered nutrient agar base for the typing of unknown organisms. This biological titration is an essential step in the technique, since the substances have a very narrow range. With substances that give a wide range the mid-point should be chosen.

The stock solutions keep for about $1 \mathrm{wk}$ in a domestic refrigerator, but should not be used beyond that time as some of the substances become more toxic and others less toxic. 
Ten times the stock concentrations of the compounds can be dispensed in 2-ml amounts and kept frozen at $-20^{\circ} \mathrm{C}$. Immediately before use they are thawed, mixed and diluted 10 times. The biological titration figure obtained for this dilution can be used for the rest of the frozen material. On present evidence the frozen ampoules keep for at least $4 \mathrm{wk}$, and possibly longer. Since this method avoids the repeated biological titrations, in practice it is a great convenience for typing.

\section{TABLE II}

Standard resistogram patterns of 16 reference strains of Escherichia coli establishing the correct volumes of the stock solutions of antibacterial agents to be added to the media

\begin{tabular}{|c|c|c|c|c|c|c|c|c|}
\hline \multirow[b]{2}{*}{ Strain } & \multicolumn{8}{|c|}{ Growth of strain on medium containing correct test concentration of } \\
\hline & $\begin{array}{l}\text { sodium } \\
\text { arsenate }\end{array}$ & $\begin{array}{l}\text { phenyl- } \\
\text { mercuric } \\
\text { nitrate }\end{array}$ & $\begin{array}{l}4: 4^{\prime} \text {-diamidino- } \\
\text { diphenylamine } \\
\text { dihydrochloride }\end{array}$ & $\begin{array}{l}\text { boric } \\
\text { acid }\end{array}$ & acriflavine & $\begin{array}{l}\text { 4-chlore- } \\
\text { sorcinol }\end{array}$ & $\begin{array}{l}\text { copper } \\
\text { sulphate }\end{array}$ & $\begin{array}{l}\text { malachite } \\
\text { green }\end{array}$ \\
\hline 1 & + & + & + & + & $(+)$ & + & - & + \\
\hline 2 & + & + & + &.+ & - & + & - & + \\
\hline 3 & + & + & + & + & - & + & + & + \\
\hline 4 & + & - & + & + & $(+)$ & + & + & - \\
\hline 5 & - & - & - & $\left(-\dashv_{-}\right)$ & + & + & - & + \\
\hline 6 & - & - & + & + & - & + & - & + \\
\hline 7 & + & + & + & + & + & - & - & + \\
\hline 8 & - & + & + & - & + & + & - & + \\
\hline 9 & - & - & - & + & + & + & + & + \\
\hline 10 & $(+)$ & - & $(+)$ & $(+)$ & + & $(+)$ & + & - \\
\hline 11 & - & $(+)$ & $(+)$ & + & + & + & - & - \\
\hline 12 & - & - & $(-+)$ & + & - & - & $(+)$ & - \\
\hline 13 & + & + & + & + & + & + & - & + \\
\hline 14 & $(+)$ & $(+)$ & + & + & $(+)$ & + & + & + \\
\hline 15 & - & + & + & + & + & + & - & + \\
\hline 16 & + & + & + & + & + & + & - & + \\
\hline
\end{tabular}

$+=$ Full confluent growth.

$(+)=$ Confluent growth of very small colonies or non-confluent growth of more than 10 colonies.

$-=$ No growth or fewer than 10 colonies.

\section{Technique of resistogram typing}

Unknown strains are most conveniently tested in batches of about 30 . Nine plates are poured: one control and one each with the respective compounds added in the amount given by the biological titration. The strains are grown overnight in $1 \mathrm{ml}$ of broth in halfounce $(10 \mathrm{ml})$ screw-capped bottles and before use are diluted 1 in 10 by the addition of $9 \mathrm{ml}$ of sterile distilled water.

It is convenient to use an inoculating machine of the type employed in phage typing. The pins should be made of stainless steel and the cups should have glass linings. Each cup receives 10 drops of sterile distilled water from a Pasteur dropper and is inoculated from the diluted overnight culture by means of a Takatsy microtitre loop. This provides the requisite inoculum size of about 1000 organisms which in the control plate should result in just-confluent growth. Before inoculation the plates are dried for $20 \mathrm{~min}$. at $37^{\circ} \mathrm{C}$. Each of the 8 plates is then inoculated, one after the other, and a reference point is marked for subsequent reading. The spots of inocula are allowed to disappear before the plates are put into the $37^{\circ} \mathrm{C}$ incubator for $18 \mathrm{hr}$.

To describe the patterns obtained each of the substances was given a letter of the alphabet 
as shown in table I. The letters attached to the substances to which the strain is resistant can then be used to describe the strain. If the strain resists sodium arsenate, for example, by giving full growth in its presence the letter $A$ is put in the description of the strain. If the organism is inhibited by it, sensitivity is denoted by the absence of the letter. Thus if an organism is resistant to all 8 substances it would receive the description ABCDEFGH.

TABLE III

Resistogram typing of 200 strains of E. coli from urinary infections

\begin{tabular}{|c|c|c|c|}
\hline Resistogram type & Number of strains & Resistogram type & Number of strains \\
\hline $\begin{array}{l}\text { BCDEFH } \\
\text { ABCDEFGH } \\
\text { ABCDEFH } \\
\text { CDEFH } \\
\text { ABCDFH } \\
\text { BDEFH } \\
\text { BCDEFGH } \\
\text { DEFH } \\
\text { ACDEGH } \\
\text { CDFH } \\
\text { ACDEFGH } \\
\text { ABCDFGH } \\
\text { DFH } \\
\text { A(B)CDH } \\
\text { ACDFH } \\
\text { ABCDF } \\
\text { A(C)DFH } \\
\text { AB(C)DE(H) } \\
\text { AB(C)D(E)FGH } \\
\text { H } \\
\text { (C)DEF(G)H } \\
\text { ABCDGH } \\
\text { BCEFH } \\
\text { CDF(G)H } \\
\text { A(B)CDEGH } \\
\text { ABDFH } \\
\text { AB(C)D(E)FH } \\
\text { (A)CDFH } \\
\text { ACD(E)(H) } \\
\text { (A)(B)CDF(G)(H) } \\
\text { A(B)DF(G)(H) }\end{array}$ & $\begin{array}{r}31 \\
21 \\
15 \\
14 \\
10 \\
10 \\
9 \\
7 \\
6 \\
4 \\
4 \\
3 \\
3 \\
3 \\
3 \\
3 \\
2 \\
2 \\
2 \\
2 \\
2 \\
2 \\
2 \\
2 \\
1 \\
1 \\
1 \\
1 \\
1 \\
1 \\
1\end{array}$ & $\begin{array}{l}\text { A(D)F(H) } \\
\text { A(B)DH } \\
\text { ACD } \\
\text { A(C)E } \\
\text { ADE(F)(H) } \\
\text { BDFH } \\
\text { BCDE(H) } \\
\text { BCD } \\
\text { (B)CDF(G)H } \\
\text { CDEGH } \\
\text { C(D)E } \\
\text { CDE(H) } \\
\text { (D)(H) } \\
\text { (A)BC(D)EFGH } \\
\text { BC(D)EFG(H) } \\
\text { (A)(C)D(E)G(H) } \\
\text { CDEFGH } \\
\text { ABCDGH } \\
\text { ABCD(G) } \\
\text { A(B)CDE } \\
\text { A(B)D(E)H } \\
\text { A(C)(D)(H) } \\
\text { ACD(E)FH } \\
\text { (A)DFH } \\
\text { ADEFGH } \\
\text { BCEFGH } \\
\text { BCDFH } \\
\text { (B)(C)DF(G)(H) } \\
\text { CDEF } \\
\text { (C)F(H) } \\
\text { (C)DF(G) }\end{array}$ & $\begin{array}{l}1 \\
1 \\
1 \\
1 \\
1 \\
1 \\
1 \\
1 \\
1 \\
1 \\
1 \\
1 \\
1 \\
1 \\
1 \\
1 \\
1 \\
1 \\
1 \\
1 \\
1 \\
1 \\
1 \\
1 \\
1 \\
1 \\
1 \\
1 \\
1 \\
1 \\
1\end{array}$ \\
\hline
\end{tabular}

Each capital letter denotes that the strain gave full growth on a medium containing the test concentration of the antibacterial agent corresponding to that letter (see table I). A letter in brackets denotes that the strain gave partially inhibited growth with the antibacterial agent.

Should it be sensitive to acriflavine and malachite green, but resistant to all others it would be ABCDFG.

Apart from full growth or total absence of growth there are two kinds of intermediate findings. There may be non-confluent growth. If single colonies appear in numbers greater than 10 per inoculum it is read as bracketed positive, e.g., (A). Fewer than 10 colonies are read as negative. The second type of resistance manifests itself in the form of confluent growth consisting of very fine colonies. This is also denoted as bracketed positive. Thus an organism may be described as $\mathrm{AD}(\mathrm{E}) \mathrm{GH}$. It was found that strains differing in their description by one bracket only should be regarded as identical. Thus $\mathrm{AD}(\mathrm{E}) \mathrm{GH}$ would be the same as ADEGH, though different from ADGH. Strains differing by a letter or by two or more brackets should be classed as different. 


\section{RESULTS}

Apart from the intermediate results recorded in brackets, tests with eight substances can give in theory 256 different combinations of results. To determine the number of types likely to be found in practice 200 unselected strains of Escherichia coli obtained from cases of urinary infection were resistogramtyped (table III). Altogether 65 types were found and no single type was present in a proportion greater than 15.5 per cent. Undoubtedly further compounds would increase the number of types found, but it was thought that eight compounds would be adequate for testing the idea under field conditions.

Fifty strains of $E$. coli isolated and fully investigated as to origin and serotype by Dr E. Mary Cooke were kindly provided by her. Only serial numbers were given initially. The resistogram types were determined for the 50 strains and set against the information as regards serotype and origin subsequently given. Table IV shows these findings. The 50 strains fell into 13 serotypes on the basis of somatic antigens and there were 14 resistogram types. In the majority of cases the two typing systems gave identical epidemiological information, i.e., strains that came from the same patients and were of the same serotype also belonged to the same resistogram type. In some cases where the origin and the serotype indicated that the strains were different the resistogram pattern failed to differentiate them. For instance, strains no. 3, 17, 33, 39, 42, 44,45 and 46 fell into a single resistogram type, CDEFH, possibly because this is a fairly common resistogram type. On the other hand, some of the strains that on the basis of their somatic serotype alone would have been regarded as probably identical gave clearly different resistogram patterns. Thus the strains obtained from patients Singleton, Crowe and Martinez were all serotype $\mathrm{O} 2$, which is a common serotype, but fell into three different resistogram types: DEFH, ACDEFH and (B)CEFH respectively. In no case did we fail to group together serologically identical strains isolated from the same patient.

\section{Discussion}

Observations of the resistance of micro-organisms to dyes for purposes of typing were first employed by Huddleson (1931) in distinguishing the different biological types of Brucella. The techniques of accurately testing sensitivity to antibiotics were not applied to antiseptics. When antiobiotic testing came to be done on a wide scale for large numbers of strains of a species it became obvious that even within a single species wide variations of susceptibility exist. Such patterns, or antibiograms, could not, however, be used as a basis for typing since antibiotics are widely employed for therapy and their presence in the environment leads to selective pressure. What was not appreciated was the fact that the variation in resistance to an antibacterial agent within a species is a general phenomenon and is not restricted to antibiotics.

Admittedly variations in sensitivity may be very fine; so fine that by ordinary disk diffusion they may pass unnoticed. Of 180 substances tested by the gradient plate method, which gives a large area over which there are relatively small concentration changes, 146 gave little or no variation within the species 
TABLE IV

Resistogram types and serotypes of 50 strains of $E$. coli from 22 patients with urinary infection

\begin{tabular}{|c|c|c|c|c|c|}
\hline Strain no. & $\begin{array}{l}\text { Name of } \\
\text { patient }\end{array}$ & $\begin{array}{l}\text { Date of } \\
\text { isolation }\end{array}$ & $\begin{array}{l}\text { Source of } \\
\text { strain }\end{array}$ & $\begin{array}{l}\text { Serotype of } \\
\text { strain }\end{array}$ & $\begin{array}{c}\text { Resistogram } \\
\text { type }\end{array}$ \\
\hline $\begin{array}{r}7 \\
9 \\
21\end{array}$ & $\begin{array}{c}\text { Clifford } \\
, "\end{array}$ & $\begin{array}{r}15.11 .68 \\
6.11 .68 \\
6.11 .68\end{array}$ & $\begin{array}{l}\text { Introitus* } \\
\text { Urine } \\
\text { Introitus }\end{array}$ & $\begin{array}{l}\text { O7 } \\
\text { O7 } \\
\text { O7 }\end{array}$ & $\begin{array}{l}\text { A(B)D(E)FH } \\
\text { A(B)D(E)FH } \\
\text { A(B)D(E)FH }\end{array}$ \\
\hline $\begin{array}{r}38 \\
47 \\
5 \\
12 \\
29 \\
11 \\
22 \\
41\end{array}$ & $\begin{array}{l}\text { Zanelli } \\
\text { Morray } \\
\text { Kidd } \\
\text { " } \\
\text { White } \\
\text { Märley }\end{array}$ & $\begin{array}{r}15.11 .68 \\
16.12 .68 \\
18.11 .68 \\
29.10 .68 \\
6.11 .68 \\
18.10 .68 \\
18.10 .68 \\
29.11 .68\end{array}$ & $\begin{array}{l}\text { Introitus } \\
\text { Introitus } \\
\text { Bladder-urine } \\
\text { Introitus } \\
\text { Urine } \\
\text { Urine } \\
\text { Introitus } \\
\text { Introitus }\end{array}$ & $\begin{array}{l}\mathrm{O} 22 \\
\mathrm{O} 22 \\
\mathrm{O} 22 \\
\mathrm{O} 22 \\
\mathrm{O} 22 \\
\mathrm{O} 22 \\
\mathrm{O} 22 \\
\mathrm{O} 22\end{array}$ & $\begin{array}{l}\text { BCDEFH } \\
\text { BCDEFH } \\
\text { BCDEFH } \\
\text { BCDEFH } \\
\text { BCDEFH } \\
\text { BCDEFH } \\
\text { (B)CDEFH } \\
\text { BC(D)EFH }\end{array}$ \\
\hline $\begin{array}{l}23 \\
30\end{array}$ & $\begin{array}{c}\text { Kingswell } \\
\text {, }\end{array}$ & $\begin{array}{l}18.10 .68 \\
18.10 .68\end{array}$ & $\begin{array}{l}\text { Introitus (1) } \\
\text { Introitus (2) }\end{array}$ & $\begin{array}{l}\mathrm{O} 23 \\
\mathrm{O} 23\end{array}$ & $\begin{array}{l}\mathrm{AB}(\mathrm{C}) \mathrm{DEFH} \\
\mathrm{AB}(\mathrm{C}) \mathrm{D}(\mathrm{E}) \mathrm{FH}\end{array}$ \\
\hline 34 & Weinberg & 18.10 .68 & Introitus & 012 & ACDFH \\
\hline 43 & Grove & 4.12 .68 & R. ureter & 025 & (B)DEFH \\
\hline $\begin{array}{r}8 \\
13 \\
14 \\
20 \\
32\end{array}$ & $\begin{array}{l}\text { Munn } \\
\text { ", } \\
, "\end{array}$ & $\begin{array}{r}15.11 .68 \\
8.11 .68 \\
8.11 .68 \\
15.11 .68 \\
8.11 .68\end{array}$ & $\begin{array}{l}\text { Urethra } \\
\text { Urine } \\
\text { Vagina } \\
\text { Introitus } \\
\text { Introitus }\end{array}$ & $\begin{array}{l}\text { O3 } \\
\text { O3 } \\
\text { O3 } \\
\text { O3 } \\
\text { O3 }\end{array}$ & $\begin{array}{l}\text { ABCDEFH } \\
\text { ABCDEFH } \\
\text { ABCDEFH } \\
\text { ABCDEFH } \\
\text { A(B)CDEFH }\end{array}$ \\
\hline $\begin{array}{l}25 \\
27\end{array}$ & $\begin{array}{l}\text { Munn } \\
\quad,\end{array}$ & $\begin{array}{l}8.11 .68 \\
8.11 .68\end{array}$ & $\begin{array}{l}\text { Urine } \\
\text { Urethra }\end{array}$ & $\begin{array}{l}\text { O18 } \\
\text { O18 }\end{array}$ & $\begin{array}{l}\text { (D)(E)FH } \\
\text { (D)(E)FH }\end{array}$ \\
\hline $\begin{array}{l}50 \\
51\end{array}$ & $\begin{array}{c}\text { Munn } \\
\text {, }\end{array}$ & $\begin{array}{l}30.12 .68 \\
30.12 .68\end{array}$ & $\begin{array}{l}\text { Vagina } \\
\text { Introitus }\end{array}$ & $\begin{array}{l}\text { O18 } \\
\text { O18 }\end{array}$ & $\begin{array}{l}\text { (C)(D)(E)FH } \\
\text { (C)(D)(E)FH }\end{array}$ \\
\hline $\begin{array}{r}4 \\
18 \\
49\end{array}$ & $\begin{array}{c}\text { Pickett } \\
\text { " }\end{array}$ & $\begin{array}{l}19.11 .68 \\
19.11 .68 \\
20.12 .68\end{array}$ & $\begin{array}{l}\text { Introitus } \\
\text { Urine } \\
\text { Bladder }\end{array}$ & $\begin{array}{l}\text { O1 } \\
\text { O1 } \\
\text { O1 }\end{array}$ & $\begin{array}{l}\text { ADFH } \\
\text { ADFH } \\
\text { ADFH }\end{array}$ \\
\hline $\begin{array}{l}24 \\
28\end{array}$ & $\begin{array}{c}\text { H.-Bradley } \\
, "\end{array}$ & $\begin{array}{l}28.10 .68 \\
11.10 .68\end{array}$ & $\begin{array}{l}\text { Introitus } \\
\text { Urine }\end{array}$ & $\begin{array}{l}\mathrm{O} 1 \\
\mathrm{O} 1\end{array}$ & $\begin{array}{l}\mathrm{AD}(\mathrm{H}) \\
\mathrm{AD}(\mathrm{H})\end{array}$ \\
\hline 35 & Martinez & 18.10 .68 & Introitus & $\mathrm{O} 2$ & (B)CEFH \\
\hline $\begin{array}{r}36 \\
2 \\
26 \\
16\end{array}$ & $\begin{array}{c}\text { Atkins } \\
\text { Crowe } \\
\text {," }\end{array}$ & $\begin{array}{r}8.11 .68 \\
22.11 .68 \\
22.11 .68 \\
22.11 .68\end{array}$ & $\begin{array}{l}\text { Introitus } \\
\text { Urethra } \\
\text { Introitus } \\
\text { Vagina }\end{array}$ & $\begin{array}{l}\mathrm{O} 4 \\
\mathrm{O} 2 \\
\mathrm{O} 2 \\
\mathrm{O} 2\end{array}$ & $\begin{array}{l}\text { ACDEFH } \\
\text { ACDEFH } \\
\text { ACDEFH } \\
\text { ACDEFH }\end{array}$ \\
\hline $\begin{array}{r}1 \\
10 \\
15 \\
6 \\
19 \\
31 \\
48 \\
37\end{array}$ & $\begin{array}{l}\text { Carver } \\
\text { ”, } \\
\text { Singleton } \\
\text { ", } \\
\text { Giles } \\
\text { Kingswell }\end{array}$ & $\begin{array}{l}25.11 .68 \\
15.11 .68 \\
25.11 .68 \\
18.11 .68 \\
18.11 .68 \\
18.11 .68 \\
16.12 .68 \\
15.11 .68\end{array}$ & $\begin{array}{l}\text { Urine } \\
\text { Introitus } \\
\text { Introitus } \\
\text { Vagina } \\
\text { Introitus } \\
\text { Urethra } \\
\text { Introitus } \\
\text { Introitus }\end{array}$ & $\begin{array}{l}\mathrm{O} 18 \\
\mathrm{O} 18 \\
\mathrm{O} 18 \\
\mathrm{O} 2 \\
\mathrm{O} 2 \\
\mathrm{O} 2 \\
\mathrm{O} 2 \\
\mathrm{O} 2\end{array}$ & $\begin{array}{l}\text { DEFH } \\
\text { DEFH } \\
\text { DEFH } \\
\text { DEFH } \\
\text { DEFH } \\
\text { DEFH } \\
\text { DEFH } \\
\text { DEFH }\end{array}$ \\
\hline $\begin{array}{r}3 \\
17 \\
42 \\
45 \\
39 \\
44 \\
45 \\
33\end{array}$ & $\begin{array}{l}\text { Gylby } \\
\text { ", } \\
\text { Morris } \\
\text { "” } \\
\text { Marks }\end{array}$ & $\begin{array}{r}11.11 .68 \\
11.11 .68 \\
29.11 .68 \\
29.11 .68 \\
22.11 .68 \\
4.12 .68 \\
2.12 .68 \\
18.10 .68\end{array}$ & $\begin{array}{l}\text { Urine } \\
\text { Introitus } \\
\text { Introitus } \\
\text { Introitus } \\
\text { Introitus } \\
\text { Introitus } \\
\text { Urine } \\
\text { Introitus }\end{array}$ & $\begin{array}{l}\text { O4 } \\
\text { O4 } \\
\text { O4 } \\
\text { O4 } \\
\text { O75 } \\
\text { O75 } \\
\text { O75 } \\
\text { O13 }\end{array}$ & $\begin{array}{l}\text { CDEFH } \\
\text { CDEFH } \\
\text { CDEFH } \\
\text { CDEFH } \\
\text { CDEFH } \\
\text { CDEFH } \\
\text { CDEFH } \\
\text { CDEF(H) }\end{array}$ \\
\hline
\end{tabular}

* Introitus of vagina.

All patients in this series had different names. 
of $E$. coli. A further 26 substances showed fair discrimination between the test strains on the gradient plates, but the concentration range between sensitive and resistant organisms proved too narrow for practical application. Thus eight substances were left, which after biological titration could be used as a basis of a resistogram system for this species.

The success of any method of typing rests on the stability of the characters chosen to describe the organism. Antibiotics are clearly unsuitable, since resistant organisms are known to occur in small numbers and the very presence of the drug will lead to the emergence of such resistant bacteria. This emergence in turn changes the antibiogram. For this reason antibiotics or any other substance likely to be present in the environment of the bacteria were excluded from our search for discriminating agents. The genetic stability of resistance to the various chemicals we have employed is not yet known. However, it must be assumed that the emergence of resistance to them is no more common than to antibiotics. Since none of the chemical substances that form the basis of our resistogram system is likely at present to be encountered by the organisms either within or outside the body, the selective pressure favouring the emergence of resistant organisms is absent. Even if resistance to one of the chemicals arises through mutation or infectious drug-resistance, the event would be so rare in relation to a single isolate obtained in epidemiological search, that it is unlikely to prove of practical significance.

There is, however, an exception to this statement. Should the character we test for in resistogram typing be genetically linked to or be located on the same plasmid as resistance to one of the antibiotics, then the selective pressure of the antibiotic would also exert selection favouring resistance to the chemical. Further work is required to explore this point, but, should such a finding emerge, that marker could be replaced by one that is free from this disadvantage.

Of the theoretical 256 possible combinations, in practice only a proportion was encountered. The largest group of a single type was 15.5 per cent. This may have been due to chance distribution, or to the fact that a given biotype predominates in urinary infections. More work is required on strains obtained from other sources to decide the point. It seems, however, that the method of resistogram typing gives epidemiologically valuable information under field conditions. In most cases the method pinpointed a strain isolated on more than one occasion from a patient with the same assurance as serotyping. In a few instances a single resistogram type described organisms that were clearly different strains-a shortcoming undoubtedly due to too few compounds being used in the system as yet. In other instances, however, common serotypes that occurred in different patients could be shown to be different strains by resistogram typing. On the whole, the results suggest that even with the use of only eight substances the method of resistogram typing is comparable in efficiency with somatic serotyping of urinary strains of E. coli. A further advantage of resistogram typing lies in the fact that every strain can be described in terms of a resistogram, whereas there are strains of $E$. coli that are serologically untypable at present.

It is not suggested that the resistogram system described here should be 
regarded as complete or permanent. Our purpose was to show that such a system is a practical possibility and that under field conditions it is capable of yielding correct answers as regards the identity of strains. Modifications and extension of the number of substances used will undoubtedly improve the system. It has been presented mainly as an illustration of a new principle that is capable of being applied to a wide variety of bacteria. For many common organisms a suitable simple typing system is still lacking, although such typing would be desirable for better epidemiological understanding.

\section{SUMMARY}

Many chemical compounds exert selective toxicity within a species of microorganism. This fact can be used to define a profile of a strain based on its resistance to selected compounds: the profile of the strain is referred to as its " resistogram". The compounds are so chosen that the organisms do not meet them under natural circumstances. Therefore, unlike the antibiotics, the compounds do not lend selective advantage to resistant elements within the population and for epidemiological purposes the resistogram type would be expected to remain stable.

The potential value of the new approach is illustrated by its application to the species Escherichia coli. A simple and rapid method of resistogram typing based on eight substances was evolved. This was applied to the study of 50 strains from urinary infections. In these strains somatic serotype and source were known, giving an indication of the extent of their diversity. Good agreement was found between serotyping and resistogram typing. In a few instances different strains fell into a single resistogram type, but in other cases strains of the same serotype from different patients could be distinguished by means of the resistogram.

We wish to express our thanks to the Endowment Fund of St George's Hospital for a generous grant which made this investigation possible.

\section{REFERENCES}

Huddleson, I. F. $\quad$. $\quad$. $\quad$. 1931. Amer. J. Publ. Hlth, 21, 491.

SZYBALSKI, W., AND BRYson, V. . . 1952. J. Bact., 64, 489. 